ECCOMAS

Proceedia
COMPDYN 2021

$8^{\text {th }}$ ECCOMAS Thematic Conference on Computational Methods in Structural Dynamics and Earthquake Engineering M. Papadrakakis, M. Fragiadakis (eds.) Streamed from Athens, Greece, 28 - 30 June 2021

\title{
EXPERIMENTAL SEISMIC POST-TENSIONING PERFORMANCE AND LONG-TERM EFFECTS OF A POST-TENSIONED TIMBER FRAMED MODEL WITH DISSIPATIVE SYSTEMS
}

\author{
A. Di Cesare ${ }^{1}$, F. C. Ponzo ${ }^{1}$, N. Lamarucciola ${ }^{1}$ and D. Nigro ${ }^{1}$
}

${ }^{1}$ School of Engineering, University of Basilicata

Viale dell'Ateneo Lucano, 10 - 85100 Potenza

\{antonio.dicesare, felice.ponzo, nicla.lamarucciola, domenico.nigro\}@unibas.it

\begin{abstract}
In recent years, post-tensioned timber framed buildings, recognized as one of the most effective sustainable and anti-seismic solutions, are developing throughout the world. Posttensioning (PT) loss in timber framed buildings with post-tensioned beam to column joints is a crucial aspect which governs the moment capacity of the connection and the global seismic performance of the frame.

This paper investigates on the variations of the post-tensioning force of a $2 / 3$ scaled, threestorey, post-tensioned timber frame experimental model investigated in three different configurations: bare frame; with dissipative rocking mechanism; with dissipative bracing system. The variation of post-tensioning during shaking table testing a set of seven spectracompatible earthquakes at increasing PGA levels has been evaluated and the long-term losses over about four years have been investigated.
\end{abstract}

Keywords: Post-tensioned timber framed buildings, Energy dissipation systems, Shaking table tests, Post-tensioning variation.

ISSN:2623-3347 (C) 2021 The Authors. Published by Eccomas Proceedia.

Peer-review under responsibility of the organizing committee of COMPDYN 2021.

doi: $10.7712 / 120121.8761 .18994$ 


\section{INTRODUCTION}

In recent years, Europe Union strategies and worldwide policies are moving towards the reduction of greenhouse gas emissions and there is an increased trend to reconsider timber as construction material for multi-storey buildings optimizing the structural concept and the seismic design, with the dual purpose to obtain more sustainable and anti-seismic constructions. In order to mitigate seismic risk and significantly reduce structural and non-structural damage avoiding high economic loss, in the last decades research studies focused on low damage design and technologies.

Recent advancement in earthquake engineering have led to the development of a prestressed laminated (Pres-Lam) technology for timber constructions. The system, originally conceived by Priestley et al. (PRESSS) [1] for precast concrete frame and wall constructions, was successfully applied to create timber jointed ductile connections [2]. It consists in the use of high strength unbounded steel cables or bars to connect timber beams and columns, or walls to their foundations, providing self-centering capability to the frame. In order to increase the seismic performance additional internal or external dampers could be added to the joints, to provide additional strength and energy dissipation capability. During the rocking motion due to earthquake or other horizontal loads, a gap opening (and connection rotation $\theta$ ) is produced, as shown in Figure 1 for the beam-column joint, activating the elongation of the unbounded post-tensioned bar $\left(\mathrm{F}_{\mathrm{PT}}+\Delta \mathrm{F}_{\mathrm{PT}}\right)$ and the yielding of the additional hysteretic dissipation devices $\left(\mathrm{F}_{\mathrm{y}}\right)$. The introduction of external metallic yielding dampers represents an optimal low-cost solution requiring a little maintenance and easily replaceable in case of damage. The combination of the moment capacity due to post- tensioning $\mathrm{M}_{\mathrm{PT}}$ (bilinear elastic response) and to yielding of steel devices $\mathrm{M}_{\mathrm{s}}$ (hysteretic response), provide the total moment capacity $\mathrm{M}_{\mathrm{t}}=\mathrm{M}_{\mathrm{PT}}+\mathrm{M}_{\mathrm{s}}$. This hybrid system allows to obtain damage-avoiding structures characterized by the typical flag-shaped response with the capability to absorb energy in a major earthquake while rocking back to an undamaged position after the shaking, resulting in negligible residual drift.
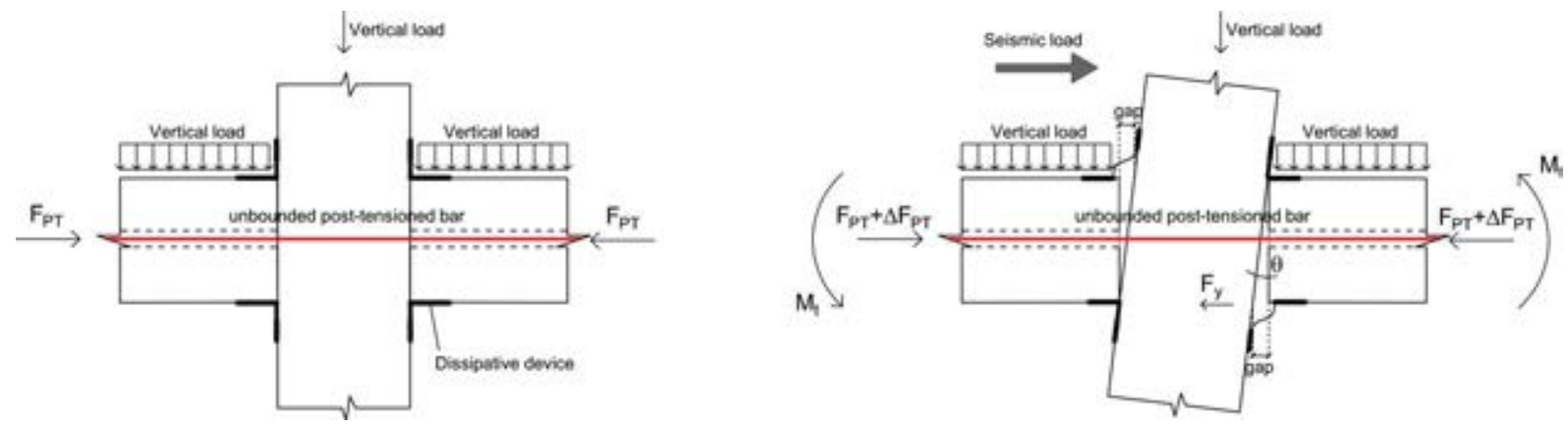

Figure 1: Undeformed configuration and post-tensioning stresses during the seismic motion of the beam-column joint.

A crucial aspect in timber building is represented by the long therm rheological effects, such as creep phenomena due to permenent loads, which can affect serviceability and structural integrity of the building. The long-term performance of post-tensioned timber systems is of interest, particularly regarding tension loss in the steel cables or bars, which can led to reduction of the moment capacity of the connection, affecting recentering capabilities and the global seismic performance of the frame [3]. Moreover, the relationship with environmental loads and creep behavior of the timber elements contribute to post-tensioning loss [4] and the horizontal motions of timber buildings can be monitored to detect residual drifts after a seismic event. To date, few research study on the post-tensoining losses of this 
recent timber construction system are avaiable in literature. Recent experimental and analytical studies [5]-[6] on post-tensioning loss deriving from creep phenomena in compressed timber elements were performed in New Zealand and Switzerland. The results showed expected losses in the range of $6-50 \%$ in 50 years in various real monitored building, such as the Trimble Navigation Offices (NZ) and the House of Natural Resources (Switzerland), mainly depending on the ratio between post-tensioning steel and timber and on the amount of timber loaded perpendicular to the grain [7].

This paper focuses on seismic post-tensioning variations and on long-term losses evaluated on a $2 / 3$ scaled, three-storey, post-tensioned timber frame experimental model tested at the structural laboratory of University of Basilicata (Italy), in collaboration with University of Canterbury (New Zealand) [8]. The experimental model was investigated in different testing configuration with increasing amount of energy dissipation and the tension losses were monitored over about four years.

\section{EXPERIMENTAL MODEL}

A three-storey post-tensioned timber frame model was designed and dynamically tested at the structural laboratory of the University of Basilicata. The prototype model was a 3D, threestorey glulam timber frame, characterized by single bays in both directions. The frame was designed according to European code [9] for office use at first and second floors (live load of $\mathrm{Q}=3 \mathrm{kPa})$ and considering a rooftop garden $\operatorname{load}(\mathrm{Q}=2 \mathrm{kPa})$. A scale factor of $2 / 3$ was applied to the experimental model obtaining an inter-storey height of $2 \mathrm{~m}$ and a scaled footprint of $4 \mathrm{~m} \times 3 \mathrm{~m}$ (Figure 2). Suitable scale factors were used observing mass similitude related to the Cauchy-Froude similitude laws [10]. The additional masses due to scaling of dead load and live load were made up of concrete blocks and steel hold downs. The beam-column connection (see Figure 1) was realized by a single unbounded post-tensioned steel bar (of 26.5 mm diameter) crossing the beam. Based on MMBA [11] procedure the tension loading of the steel bar was $100 \mathrm{kN}$ and $50 \mathrm{kN}$ for the longitudinal and transversal direction, respectively.

The three following testing configurations, with different amount of energy dissipation [8][12][13], were considered: i) bare post-tensioned frame (F) shown in Figure 3a, representing the free rocking condition with post-tensioning only without energy dissipation; ii) dissipative frame (DF), representing the bare frame (F) with additional dissipative rocking at the beam-column joints and at the column-foundation connection; and iii) braced frame (BF) shown in Figure $3 \mathrm{~b}$, representing the bare frame $(\mathrm{F})$ with dissipative braces.

The seismic response of the frame was recorded by more than 50 acquisition channels. Different types of sensors were installed on the test frame, providing measurements of horizontal and vertical accelerations, absolute displacements, strain and force. Among various monitored parameters, the tendon's load was recorded by 6 load cells placed at the beam-column joints (see Figure 2), in both longitudinal and transversal directions of the experimental model in all configurations. For more information about the experimental model and data acquisition please refer to Di Cesare et al. [8]. In this study, seismic post-tensioning losses during shaking table tests and the long-term post-tensioning losses among the various configurations have been investigated. 


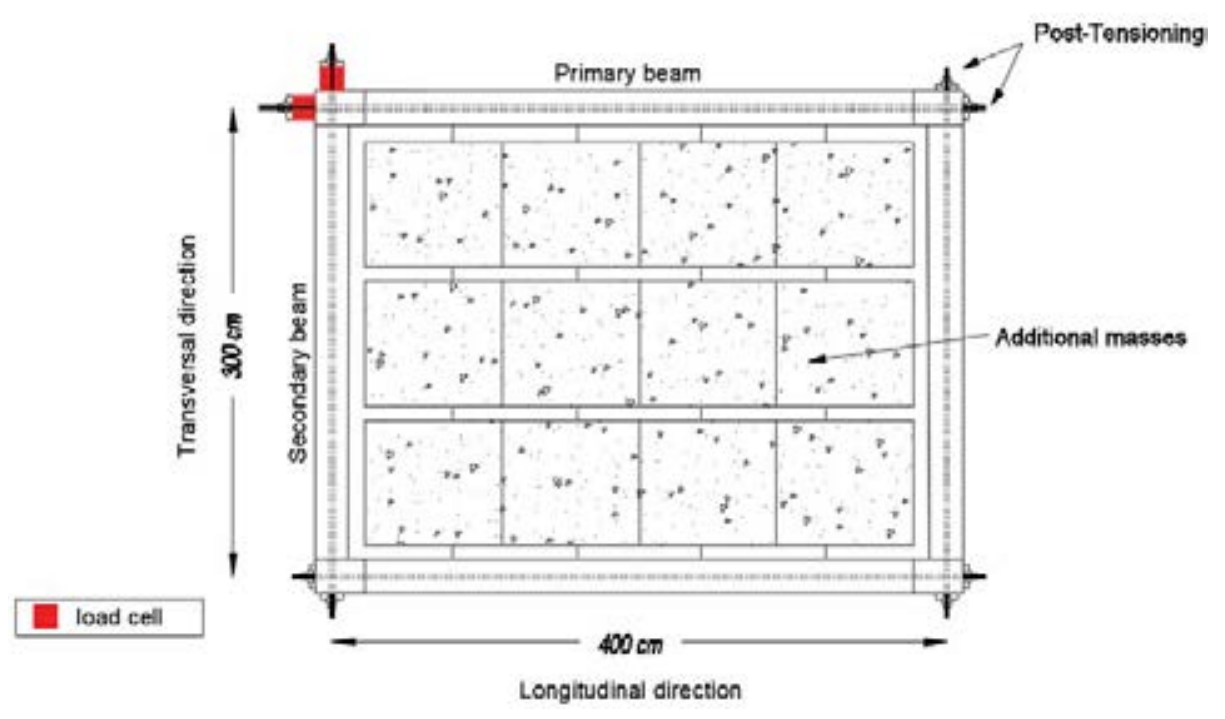

Figure 2: Plan view of timber frame with location of post-tensioned bars.

(a)

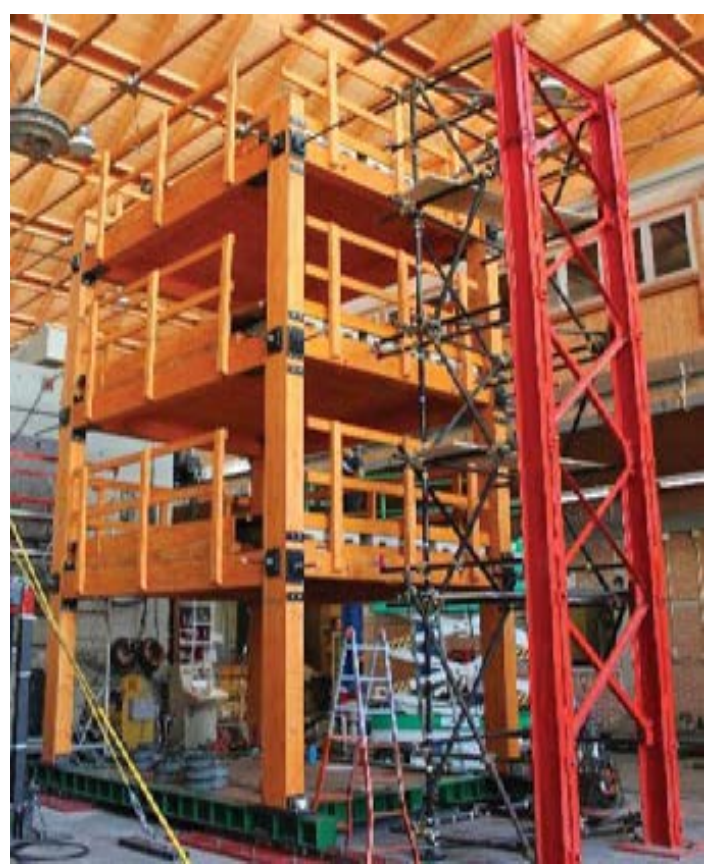

(b)

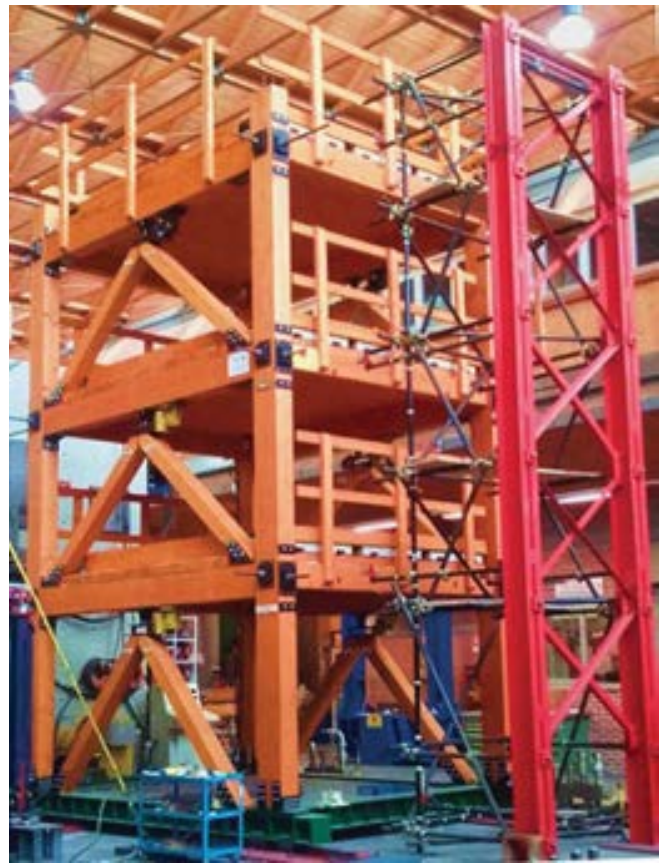

Figure 3: General views of experimental model at the structural laboratory of University of Basilicata: (a) posttensioned timber bare frame (F configuration); (b) post-tensioned model with dissipative bracing systems (BF configuration).

\section{POST-TENSIONING VARIATIONS}

\subsection{Variations due to seismic motion}

The experimental campaign was performed using a set of seven natural earthquake records, selected from the European strong motion database. The spectra-compatible records were defined according to the current Eurocode [9] considering a peak ground acceleration PGA of $0.44 \mathrm{~g}$ and medium soil class (type B) in high seismic zone. To ensure consistency with the scale of the experimental model, all input accelerations were scaled down in duration by a 
factor of $1 / \sqrt{ }(3 / 2)$. In order to match the real acceleration inputs to the Eurocode response spectrum it was necessary to scale some earthquakes by means of an appropriate scale factor.

The reduced set of three spectra-compatible earthquakes selected in this paper and the shake table testing program of all experimental configurations are summarized in Figure 4. The intensity of the ground motion was progressively increased in acceleration for earthquake cases $1228,196,535$ from $10 \%$ to $100 \%$ of average PGA for DF and BF configurations, in order to provide additional information regarding the frame response at varying damage levels.

\begin{tabular}{cccc}
\hline $\begin{array}{c}\text { PGA } \\
(\%)\end{array}$ & \multicolumn{3}{c}{ Seismic inputs } \\
\hline 10 & F, DF, BF & F, DF, BF & F, DF, BF \\
25 & F, DF, BF & F, DF, BF & F, DF, BF \\
50 & F, DF, BF & F, DF, BF & F, DF, BF \\
75 & F, DF, BF & F, DF, BF & F, DF, BF \\
100 & F, DF, BF & DF, BF & DF, BF \\
\hline
\end{tabular}

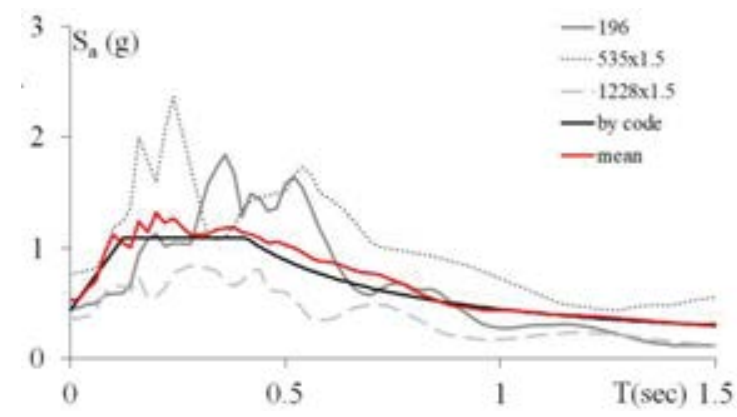

Figure 4: Testing program for selected seismic inputs of the experimental model and selected seismic inputs.

During shaking table tests the tension load has been recorded and the post-tensioning variation $\Delta \mathrm{F}_{\mathrm{PT}}=\left(\mathrm{F}_{\mathrm{PT} \text {,max }}-\mathrm{F}_{\mathrm{PT} \text {,initial }}\right)$ for the three testing configurations $(\mathrm{F}$, $\mathrm{DF}$ and $\mathrm{BF})$ has been evaluated. The maximum and mean variation of post-tensioning force $\Delta \mathrm{PT}$ are shown in Figure 5 for all configurations at increasing PGA levels. As can be observed, the introduction of the bracing system was effective in reducing the post-tensioning of over $50 \%$ than $\mathrm{F}$ configuration.

Figure 6 shows the time histories of the post-tensioning variation $\Delta \mathrm{FPT}_{\mathrm{PT}}$ of the first storey beam-column connection and Figure 7 and Figure 8 show $\Delta \mathrm{FPT}_{\mathrm{PT}}$ versus drift for the three selected seismic inputs at $25 \%$ and $75 \%$ of PGA level of all testing configurations. As can be observed at low PGA level of all seismic inputs the PT bar was slightly activated with a maximum PT variation of $12 \mathrm{kN}$ in F model configuration due to the elastic response of the frame model. At PGA 75\% the re-centering effect due to the post-tensioning is more evident in all configurations. It can be observed that increasing amount of energy dissipation introduced in the frame (from $\mathrm{F}$ to DF and to BF configurations) led to a significant reduction of drift and of post-tensioning force variation demonstrating the effectiveness of the design procedure. In all cases a complete re-centering of the connection is observed without damages on the structural elements in all configurations tested.

Seismic post-tensioning losses due to subsequent earthquakes have been also investigated, considering the complete sequence of shaking table testing at all PGA levels (from $10 \%$ to $100 \%$ ). The post-tensioned bars were tensioned to the design PT force of $100 \mathrm{kN}$ in the test direction only at the beginning of each test configuration ( $\mathrm{F}, \mathrm{DF}$ and $\mathrm{BF}$ model). Figure 9 shows the post-tensioning loss at the end of seismic sequence, defined as the variation between the initial and the final value of the post-tensioning force recorded within the complete set of ground motion for each testing configuration at all levels both in longitudinal and transversal direction. It results negligible for the cases of bare frame $\mathrm{F}$ and of braced frame $\mathrm{BF}$ models and slightly higher than $2 \%$ for the dissipative frame DF model along the longitudinal direction due to the strengthening effect of dissipative angles of the post-tensioned beamcolumn joints. Results highlight the capability of the building to withstand multiple consecutive strong earthquakes. During the experimental campaign over than 100 tests were performed for each configuration without observing any structural damage. 


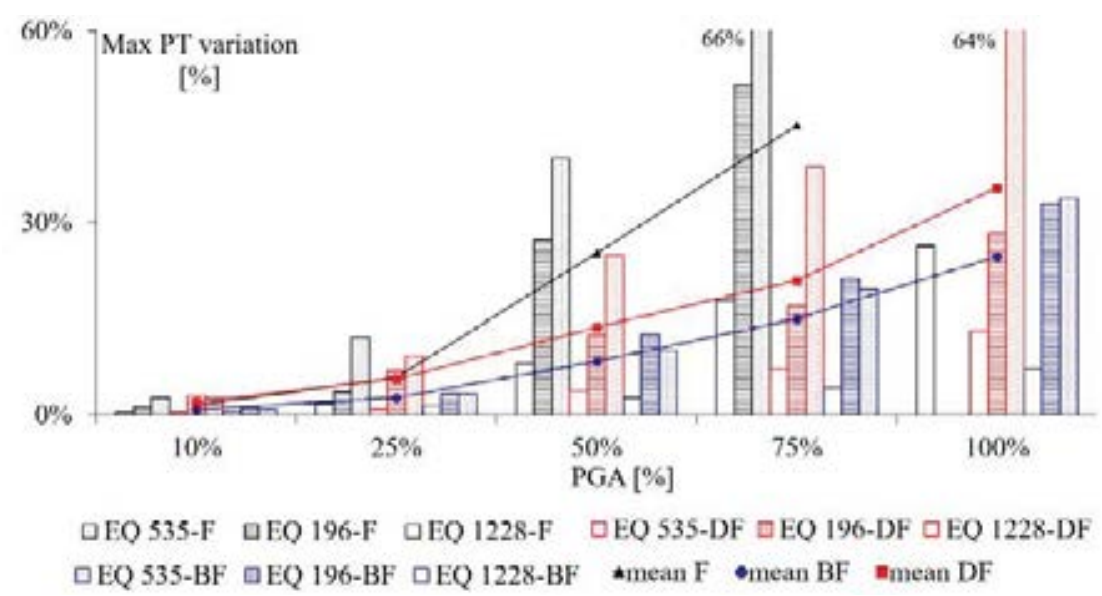

Figure 5: Maximum post-tensioning force variation profiles at increasing PGA levels for the three selected seismic inputs.

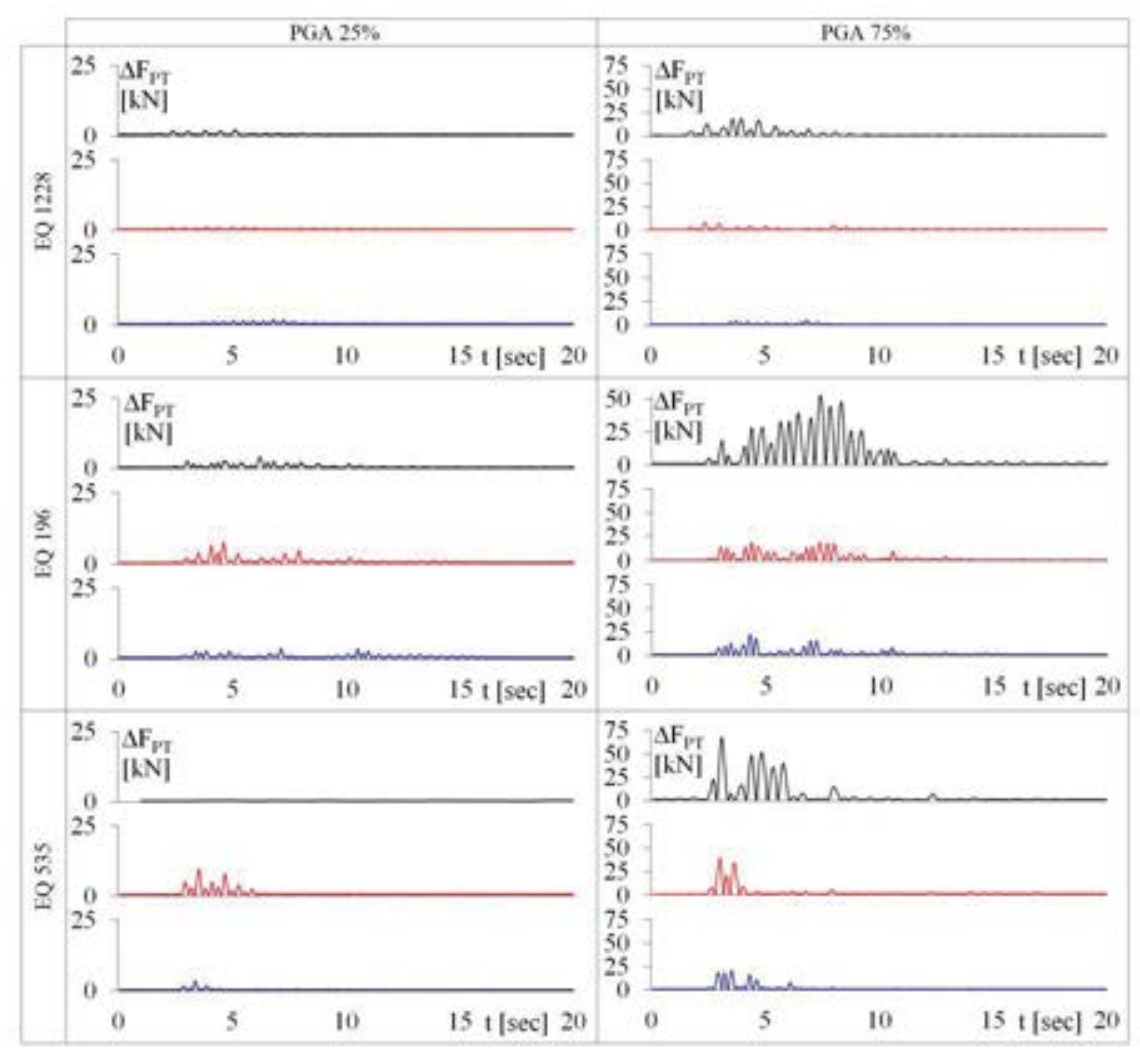

Figure 6: Post-tensioning variation time histories at the first storey beam-column connection for seismic inputs 1228,196 and 535 at $25 \%$ and $75 \%$ of PGA levels. 


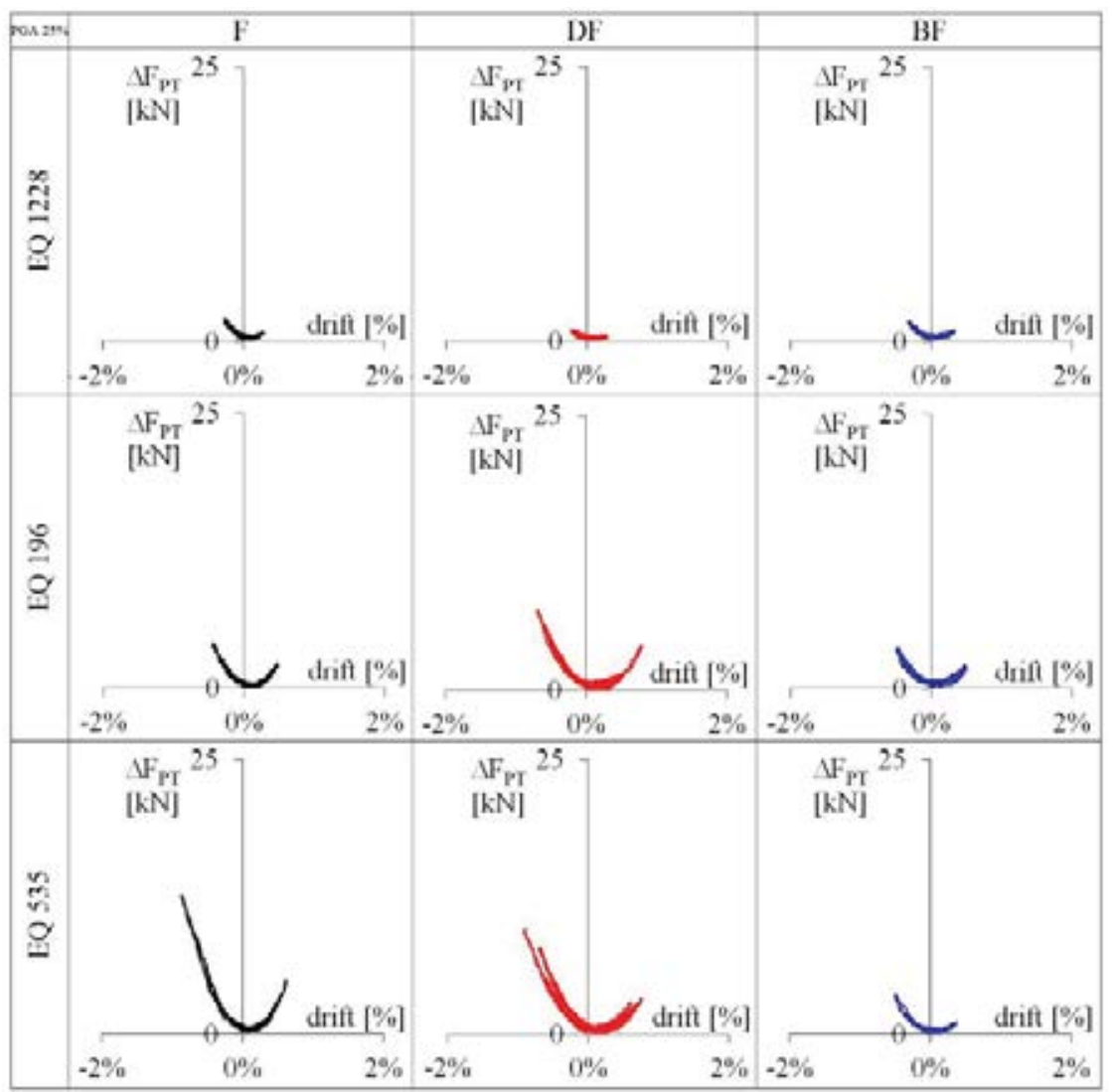

Figure 7: Post-tensioning variation versus drift for the three selected seismic inputs at $25 \%$ of PGA.

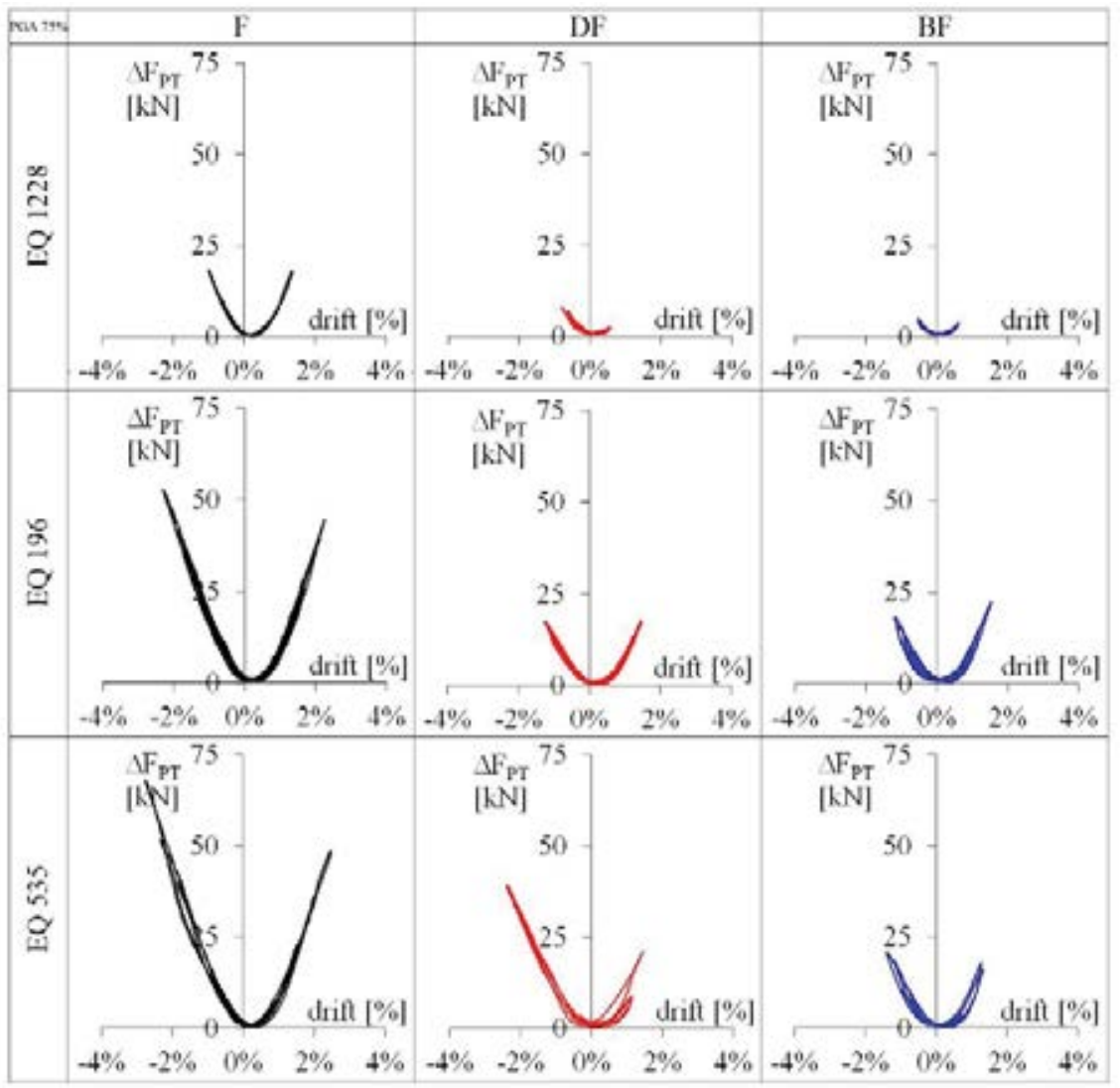

Figure 8: Post-tensioning variation versus drift for the three selected seismic inputs at $75 \%$ of PGA. 


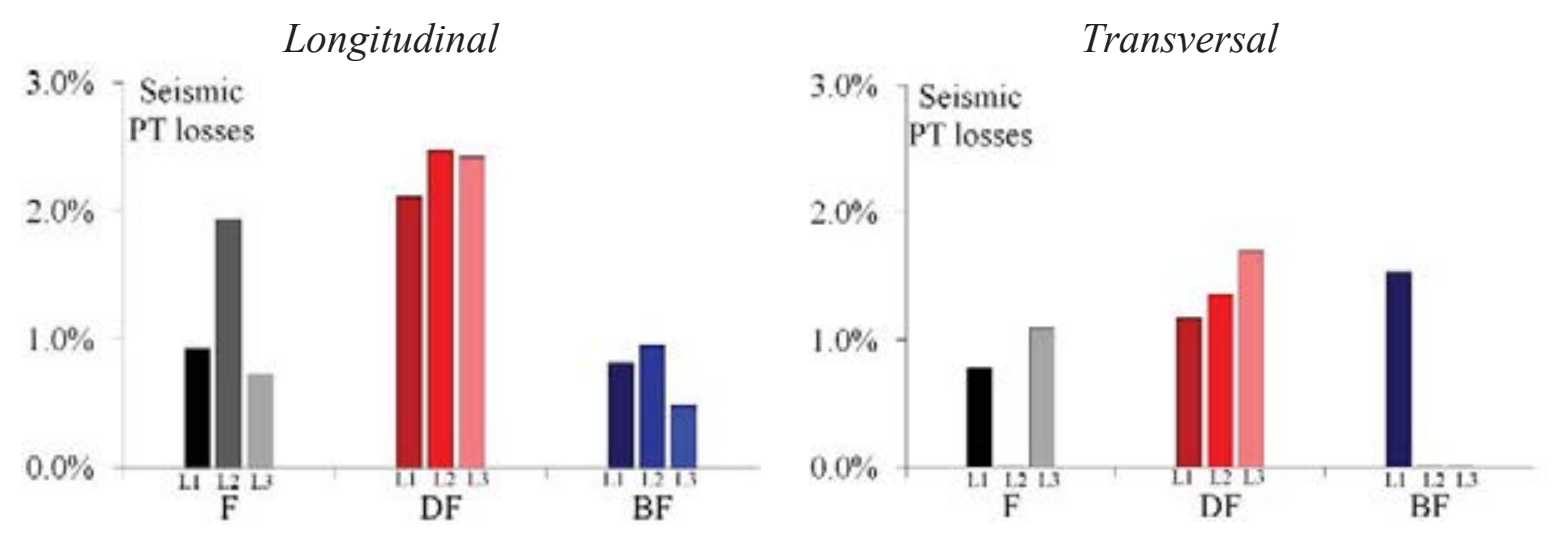

Figure 9: Seismic post-tensioning losses recorded for the three testing configurations at the three levels in longitudinal and transversal direction.

\subsection{Variations due to long term effects}

The long-term post-tensioning losses at all levels both in longitudinal and transversal direction of bare frame $\mathrm{F}$ and dissipative frame DF configurations are shown in Figure 10 in terms of post-tensioning force $\left(\mathrm{F}_{\mathrm{PT}}\right)$ recording over a time period of about one year after testing of $\mathrm{F}$ configuration and over about three years after testing of DF configuration. Percentages values of post-tensioning losses are reported in Table 1.

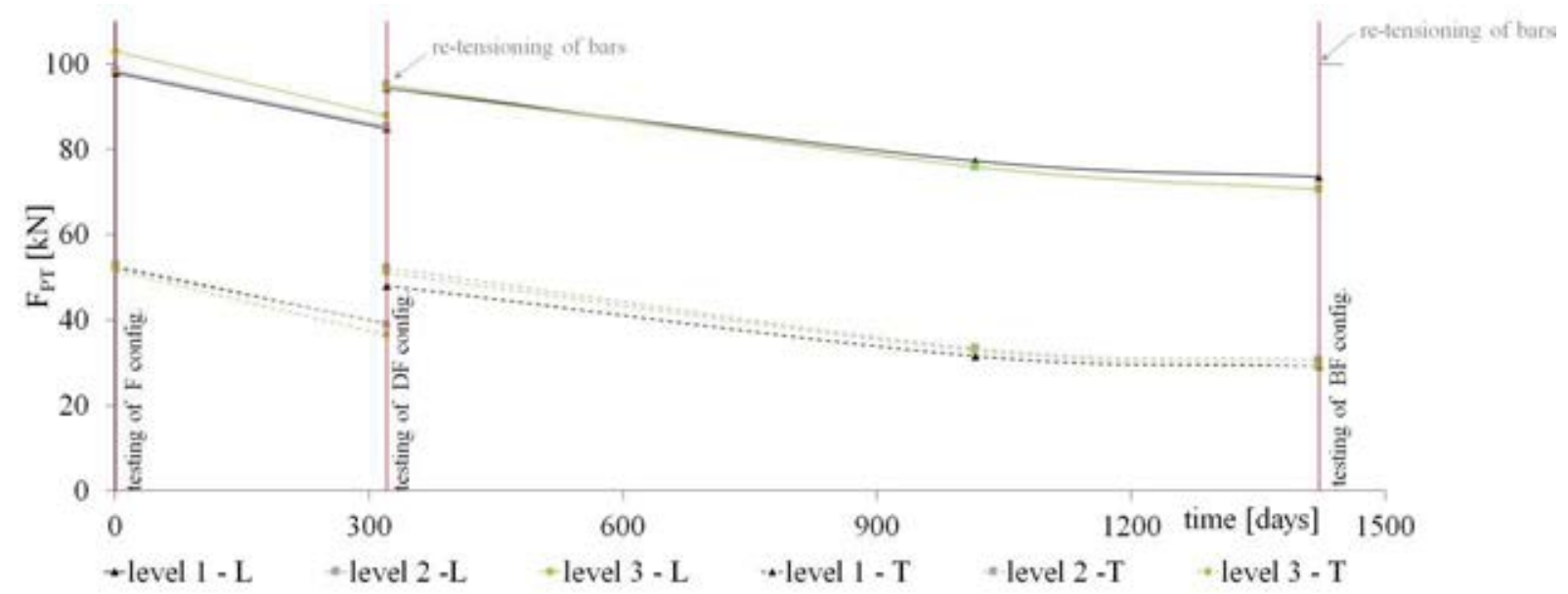

Figure 10. Post-tensioning losses over time for $\mathrm{F}$ and DF configurations at all storey in longitudinal (L) and transversal $(\mathrm{T})$ directions.

\begin{tabular}{cc|ccc|ccc}
\hline & \multicolumn{8}{c}{ Post tensioning losses [\%] } \\
Longitudinal & \multicolumn{3}{c}{ Transversal } \\
\hline $\begin{array}{c}\text { Model } \\
\text { Config. }\end{array}$ & $\begin{array}{c}\Delta \mathrm{t} \\
{[\text { days }]}\end{array}$ & $1^{\text {st }}$ storey & $2^{\text {nd }}$ storey & $3^{\text {rd }}$ storey & $1^{\text {st }}$ storey & $2^{\text {nd }}$ storey & $3^{\text {rd }}$ storey \\
\hline F & 321 & $15 \%$ & $13 \%$ & $13 \%$ & $29 \%$ & $27 \%$ & $25 \%$ \\
\hline DF & 1101 & $25 \%$ & $26 \%$ & $22 \%$ & $43 \%$ & $41 \%$ & $39 \%$ \\
\hline
\end{tabular}

Table 1. Post-tensioning losses recorded over time at all storey for the $\mathrm{F}$ and DF configurations. 
As expected, a decreasing trend of post-tensioning force was observed in both $\mathrm{F}$ and DF configurations. It can be pointed out that in case of DF configuration after a period of about 2 years the post-tensioning losses stabilized at around $25 \%$ in the longitudinal direction. Highest post-tensioning losses were recorded for both $\mathrm{F}$ and DF in the transversal direction. Moreover, by comparing the trend of post-tensioning force recorded for $\mathrm{F}$ and $\mathrm{DF}$ specimens during the first year both in the longitudinal and transversal direction, lower post-tensioning losses were be observed in the frame with dissipative rocking mechanism at the beam-column connections. During each configuration the bars were not re-tensioned over time and posttensioning losses can be significant when the PT connection is left to transfer the posttensioning load. However, in case of operative timber structures the effect of long-term losses can be contrasted by using disc springs designed for the initial PT force, characterized by high load capacity with a small spring deflection, and periodically monitored and/or re-tensioned.

\section{CONCLUSIONS}

This paper investigates on the long-term and seismic post-tensioning losses of a $3 \mathrm{D}$, three storey, 2/3 scaled post-tensioned timber framed building designed and tested at the structural laboratory of Basilicata. The extensive shaking table testing campaign was performed in three different configurations, considering the bare frame with post-tensioning only, with dissipative rocking mechanisms and with dissipative bracing systems, subjected to different seismic inputs at increasing PGA levels. During each testing configuration the frame was not retensioned.

The results showed that during the seismic motion, the variation of post-tensioning force at due to the rocking at the beam-column joints and the gap opening reduced with the introduction of dissipative systems, in DF and BF configurations. Moreover, the post-tensioning losses recorded within the complete set of ground motions for each testing configuration at all levels both in longitudinal and transversal direction were negligible. The maximum recorded value was of about $2 \%$ in DF configuration due to the strengthening effect of dissipative angles. The long term the post-tensioning force decreased linearly in the first two 2 years, reaching a $25 \%$ of losses, after that responded almost constant.

\section{AKNOWLEDGEMENTS}

Authors would like to acknowledge financial support from RELUIS 2019-2021 project (www.reluis.it) funded by the Italian Civil Protection Department.

\section{REFERENCES}

[1] Priestley M.J.N., Sritharan S., Conley J.R., Pampanin S. (1999). Preliminary Results and Conclusions from the PRESSS Five-Story Precast Concrete Test Building. PCI Journal, 44.

[2] Palermo A., Pampanin S., Buchanan A. and Newcombe M.P., (2005) Seismic Design of Multi-Storey Buildings using Laminated Veneer Lumber (LVL), NZSEE Conference, Taupo, New Zealand. 
[3] Baas, E. J., Riggio, M., \& Barbosa, A. R. (2021). A methodological approach for structural health monitoring of mass-timber buildings under construction. Construction and Building Materials, 268, 121153.

[4] Granello, G., Palermo, A., Pampanin, S., Smith, T., \& Sarti, F. (2018). The implications of post-tensioning losses on the seismic response of Pres-Lam frames. Bulletin of the New Zealand Society for Earthquake Engineering, 51(2), 57-69.

[5] Wanninger, F., Frangi, A., \& Fragiacomo, M. (2015). Long-term behavior of post-tensioned timber connections. Journal of Structural Engineering, 141(6), 04014155.

[6] Granello, G., Leyder, C., Frangi, A., Palermo, A., \& Chatzi, E. (2019). Long-term performance assessment of an operative post-tensioned timber frame structure. Jour-nal of Structural Engineering, 145(5), 04019034.

[7] Granello, G., \& Palermo, A. (2020). Monitoring Dynamic Properties of a Pres-Lam Structure: Trimble Navigation Office. Journal of Performance of Constructed Facilities, 34(1), 04019087.

[8] Di Cesare, A.; Ponzo, F.C.; Lamarucciola, N.; Nigro, D. (2020) Dynamic Seismic Response of Nonlinear Displacement Dependent Devices Versus Testing Required by Codes: Experimental Case Studies. Applied Science, 10, 8857.

[9] UNI EN 1998-1 (2013) EUROCODE 8: design of structures for earthquake resistancepart 1: general rules, seismic actions and rules for buildings. European Committee for Standardization, Brussels, Belgium.

[10] Krawinkler H., and Moncarz P. D. (1981) Theory and Application of Experimental Model Analysis in Earthquake Engineering. Standford, CA: NASA STI/Recon Technical Report N 82.

[11] Newcombe, M. P., Pampanin, S., A.Buchanan, and Palermo, A. (2008). "Section Analysis and Cyclic Behavior of Post-Tensioned Jointed Ductile Connections for Multi-Story Timber Buildings." Journal of Earthquake Engineering, 12(1), 83-110.

[12] Ponzo, F.C.; Di Cesare, A.; Lamarucciola, N.; Nigro, D., Pampanin S. (2017). Modelling of post-tensioned timber-framed buildings with seismic rocking mechanism at the column-foundation connections. International Journal of Computational Methods and Experimental Measurements, Vol. 5, Issue 6, Pages 966-978.

[13] Ponzo, F.C.; Di Cesare, A.; Lamarucciola, N.; Nigro, D. (2019). Seismic design and testing of post-tensioned timber buildings with dissipative bracing systems. Front. Built Environ., 5, 104, doi:10.3389/fbuil.2019.00104. 